\title{
35. Cymathaere crassifolia (Postels et Ruprecht) De Toni from the Southern Kuriles.
}

\author{
By Kingo Mryabe and Masaji Nagai.
}

(Comm. by K. MrYabe, M.1.A., April 12, 1932.)

Postels and Ruprecht described and illustrated in 1840 two triplicated species of Laminaria from the Northern Pacific. They are Laminaria crassifolia Post. et Rupr. and Laminaria triplicata Post. et Rupr. On the latter species J. G. Agardh established a new genus Cymathaere, characterized by three longitudinal folds in the median portion of the lamina and discoid holdfast. Cymathaere triplicata J. Ag. has a wide range of distribution in the Northern Pacific, from Puget Sound to Bering Island and also extending to the Kurile Islands,Shumushu (K. Yendo, and M. Nagai), Alaid (H. Ito and G. Komori), Paramushir (M. Nagai), Shimushir (M. Nagai), Urup (M. Nagai) and Etorofu (M. Nagai).

From the description and illustration of Laminaria crassifolia by Postels and Ruprecht, it seems to have been based on a single old depauperated specimen collected on the eastern coast of Kamtchatka most likely late in season either in 1827 or 1828. It was noted as growing with Arthrothamnus bifidus J. Ag. and to be rare. For more than a century no one has succeeded to prove its existence in the North Pacific Region, until it was unexpectedly found by the junior author on the eastern coast of Kunashiri, the southernmost island of the Kuriles, in 1929 and 1931.

De Toni has with right judgment transferred Laminaria crassifolia $\mathrm{P}$. et R. to the genus Cymathaere J. Ag. making the necessary emendation to its generic character, as the plant has the holdfast of branched hapteres.

\section{Cymathaere crassifolia (Post. et Rupr.) De Toni}

Sylloge Algarum III. p. 360, 1895.

Syn. Laminaria crassifolia Post. et Rupr. Illustr. Alg. p. 10, t. 38, f. d, 1840 ; J. Ag. Sp. I. p. 136 ; Kuetz. Sp. p. 574 ; Le Jolis Genre Lamin. p. 72.

Jap. name. Atsuba-misujikombu, Umanokawa (local name).

$H a b$. Growing in the depth of $4-5$ fathoms. 
Kamtchatka. Petropavlovsk (Russian Collector, 1827 or 1828).

Kuriles. Kunashiri Isl. : Seoi at the eastern coast (M. Nagai and M. Shimamura, Aug. 1929), Odaibake also at the eastern coast (M. Nagai, Aug. 1931).

Holdfast composed of 4-7 times dichotomously branched hapteres; stipe rigid, conspicuously or slightly flattened at the upper portion, longitudinally rugulose-striate, $3.5-7 \mathrm{~cm}$. in length, 6-8 $\mathrm{mm}$. in diameter, with large closely arranged mucilage lacunae in subcortical layer; blade simple, linear-oblong or linear-obovate with rounded or subcordate and more or less inequilateral base, possessing three longitudinal parallel folds extending throughout the length of the blade at its median portion, thick and coriaceous in the basal and median portions, thinner and less coriaceous and more or less wavy in the margin and upper portion, with a row of mucilage lacunae arranged rather closely in the outer portion of the cortex, 1-1.86 meter in length, 9-18 cm. in width at the basal portion, $20-35 \mathrm{~cm}$. wide at the middle portion; sori extended on the basal and median portions of the blade.

The blade of this kelp becomes so exceedingly mucilagino-gelatinous on the surface, when moistened with fresh water, that it makes difficult to dry it in a sandy beach. This peculiar character was already observed in the Kamtchatkan specimen by Postels and Ruprecht.

The authors wish to acknowledge their indebtedness for the fund granted by the Imperial Academy for carrying out the research on the Laminariaceae of Japan.

\section{Explanation of Figures.}

Fig. 1. Entire view of the plant. 1/5.

Three parallel folds percurrent to the extremity of the blade are shown distinctly.

Fig. 2. Showing the lower portion of the frond, stipe and holdfast. 1/2.

Fig. 3. Cross section of the stipe, showing the closely arranged mucilage lacunae in the subcortical layer. $\times 160$.

Fig. 4. Cross section of the blade, showing a row of the mucilage lacunae in the outer portion of the cortex. $\times 160$. 


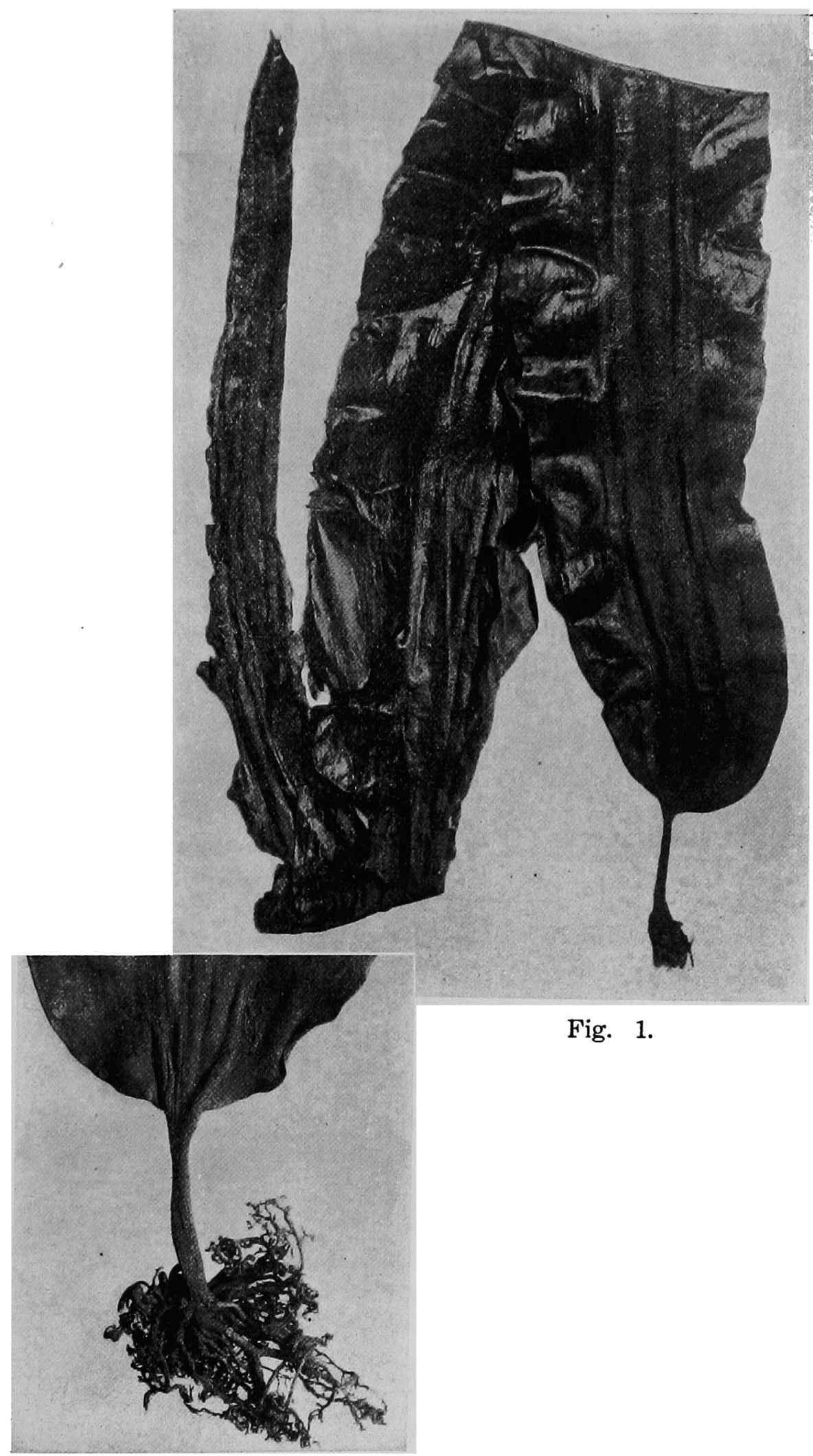

Fig. 2. 


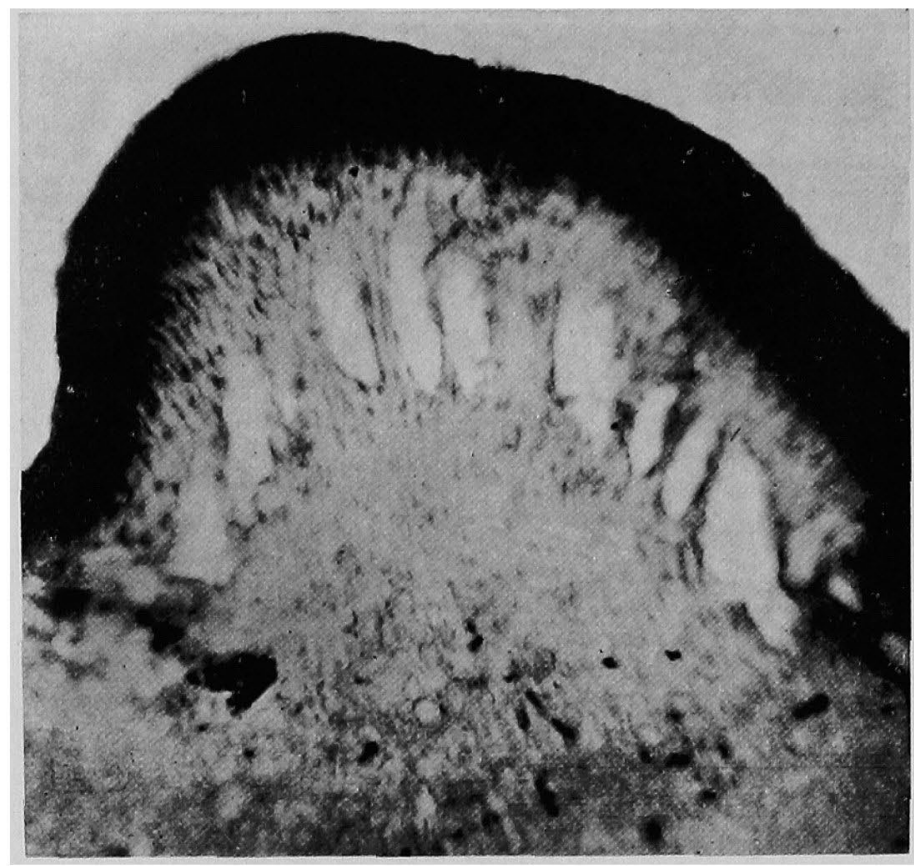

Fig. 3.

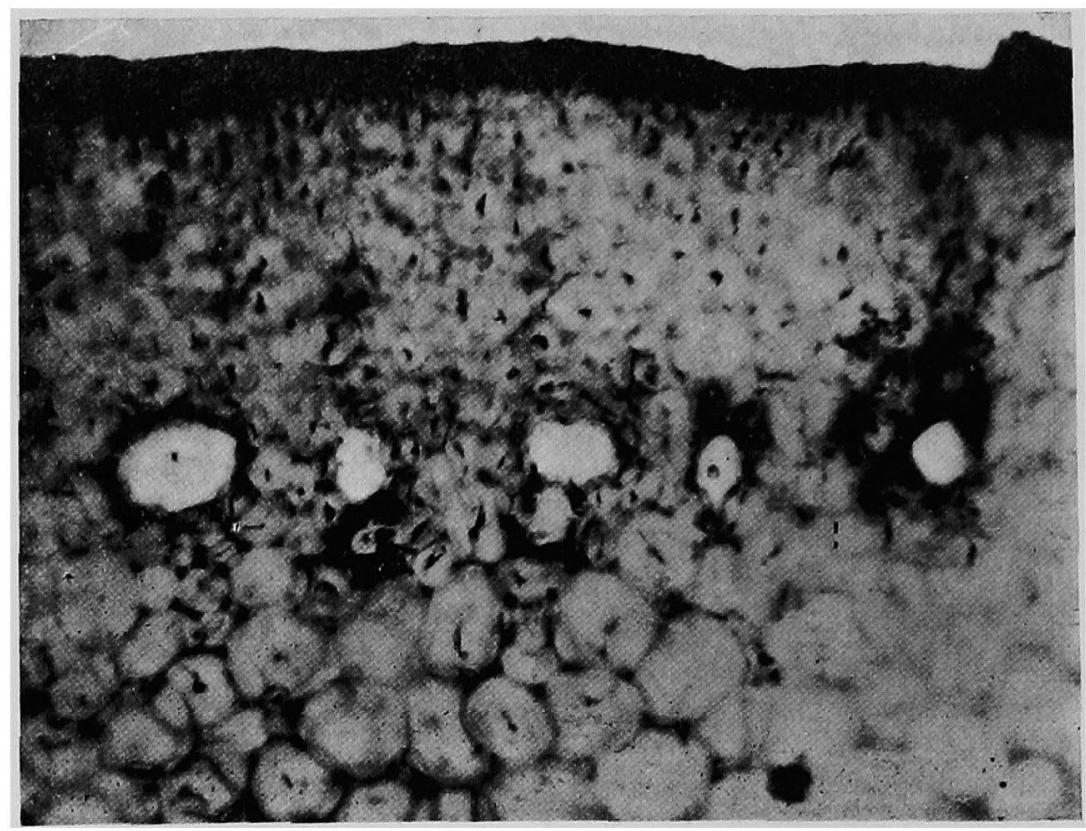

Fig. 4. 